Social Work/Maatskaplike Werk Vol 50 No 3; (4)

http://socialwork.journals.ac.za/pub. http://dx.doi.org/10.15270/50-2-405

SUBSTANCE ABUSE AMONGST THE YOUTH IN GRABOUW WESTERN CAPE: VOICES FROM THE COMMUNITY

Naome Mudavanhu, Rinie Schenck, University of the Western Cape Bellville, South Africa

\title{
Abstract
}

This article describes the reasons of substance abuse among the youth in Grabouw, Western Cape Province of South Africa. The research was conducted at the request of the community of Grabouw. The ecological approach was followed as a theoretical framework. A qualitative research methodology was used to explore the phenomenon under study. The research followed an explorative, descriptive and contextual research design. The findings showed that the reasons for substance abuse among youths in Grabouw include multiple personal and contextual factors in which the family plays a major role. 



\section{SUBSTANCE ABUSE AMONGST THE YOUTH IN GRABOUW WESTERN CAPE: VOICES FROM THE COMMUNITY}

\section{Naome Mudavanhu, Rinie Schenck}

\section{CONTEXT OF THE STUDY}

The study explored the reasons for substance abuse amongst the youth in Grabouw, a town some $80 \mathrm{~km}$ east of Cape Town, in the Western Cape Province of South Africa. The reason for the research, conducted at the request of the community of Grabouw, was the high prevalence of substance abuse amongst youths in this community. The University of the Western Cape, the base for this study, has a long-standing relationship with the Theewaterskloof Municipality; Grabouw is one of the towns in this municipality.

The $3^{\text {rd }}$ Generation Integrated Development Plan (IDP, 2012-2017) of the Theewaterskloof Municipality showed that some sectors of the community are wealthy, but the majority of the community are poor; high unemployment rates and low income rates are prevalent; most people in Grabouw live on some form of government grant; there is a housing shortages and a lack of high school education in this area. Jacobs (2012) states that the unemployment rate in the area is more or less $40 \%$ and, because of seasonal work, this unemployment rate rises at the off-season time $\left(3^{\text {rd }}\right.$ Generation IDP 2012-2017).

It is within this context that substance abuse amongst the youth will be investigated.

\section{OVERVIEW OF SUBSTANCE ABUSE AMONGST THE YOUTH}

Parrott, Morinan, Moss and Scholey (2004) identified that adolescents start using drugs by the age of 12 years. Substance abuse usually starts by experimenting with smoking cigarettes in the school toilets during breaks and this later advances to using other drugs such as cannabis, crystal meth and alcohol (Berk, 2007; Donald, Lazarus \& Peliwe, 2007). Substance abuse occurs for various reasons; there are causative issues such as family problems, influence from peers, stressful situations and the developmental stage (Jaffe, 1998; Liddle \& Rowe 2006; Rice \& Dolgin, 2008). According to Hoberg (2001), there has been an rapid growth in substance use among adolescents worldwide. He further refers to the "alarming increase in the popularity of club drugs" among schoolgoing adolescents. Visser (2003) confirms that trends worldwide indicate that when a country undergoes general and radical socio-economic change, as is presently occurring in South Africa, these changes are reflected in the spheres of risk-taking behaviour, for instance, substance abuse. Chopra and Saunders (2004) further noted that with South Africa's integration into the global economy, it lost its several protective trade barriers and people are now more prone to be exposed to substance abuse and drug trafficking.

According to Seggie (2012) and Botes (2012), alcohol is seen as the most frequently used drug and approximately $30 \%$ of the population in South Africa have a drinking 
problem. Furthermore, figures show that young people have a high risk of developing drinking problems, while people between the ages of 18 and 22 are recorded as the ones with serious alcohol-abuse problems. A study on the rural and wine farm populations in the Western Cape Province, where Grabouw is situated, has demonstrated that about 5\% of children starting school have Foetal Alcohol Syndrome Disorder as a consequence of alcohol use/abuse by their mothers while pregnant (SACENDU, 2011). Ramlagan, Peltzer and Matseke (2010) further mention that some of the perceived reasons for drug abuse in South Africa are poverty, idleness, living in an area surrounded by substance users, long working hours and living a stressful life. According to the United Nations Office on Drugs and Crime (UNODC) (2008), substance abuse is aggravated by multifaceted socio-economic challenges such as joblessness, poverty and crime in general, with these societal problems distressing a lot of communities. Drug dealers are manipulating young people into using substances, so that once they are addicted they can also influence their friends to take these substances (UNODC, 2008). Many young people appear to consider substance experimentation as a standard part of shifting into adulthood, without realising the negative consequences of substance dependence (Madu \& Matla, 2003).

In responding to the request from the community, the research aims to explore and describe the reasons for substance abuse amongst the youth in Grabouw.

\section{THEORETICAL FRAMEWORK FOR THE RESEARCH}

The study was guided by the Bronfenbrenner's ecological systems theory of human development and socialisation as theoretical framework as it looks at individuals in their environments. The ecological systems theory maintains that it is vital to note that an environment and its immediate settings actively shape the outcome of an individual's life. People do not live in isolation but rather within multifaceted structures that contain their immediate settings, social networks and traditional communities established in a wider social structure (Adams, Dominelli \& Payne, 2009; Hepworth, Rooney, Rooney \& Larson, 2008; Howe, 2009; Kirst-Ashman \& Hull, 2009).

Bronfenbrenner (1989) proposed that people are both producers and products of their development, which means that a human infant is naturally prone to act on his or her surroundings. He also states that people have distinct features that invite or reject responses from the environment and in so doing they foster or discourage development (Bronfenbrenner, 1989). One of the main assumptions of the ecological theory is that an individual and his background both have an impact on each other (Green, 2011). This theoretical model will be applied in the discussion of the results.

\section{RESEARCH METHODOLOGY}

A qualitative research approach was applied in this research. McRoy (in De Vos, Strydom, Fouché \& Delport, 2011) states that the qualitative approach is rooted in an anti-positivist and interpretive methodology (Banister, Burman, Parker, Taylor \& Tindal, 1998; Creswell, 2009; De Vos et al., 2011). Qualitative research is further defined by Creswell (2009:249) as "an inquiry process of understanding based on a distinct 
methodological tradition of inquiry that explores a social or human problem and the researcher builds a complex, holistic picture, analyses words, reports, detailed views of the informants and conducts the study in a natural setting." Qualitative research targets for depth rather than quantity of understanding, since this is actually the kind of independence and natural growth of action that the researcher needs to capture (Henning, Van Rensburg \& Smit, 2004). This research needed to hear from the youths, parents and community of Grabouw what they perceive to be the main reasons for substance abuse amongst the youth.

Flick (1992) defines the research design as an idea for accumulating plus analysing the data that makes it conceivable for the researcher to answer the questions formulated (De Vos et al., 2011). An exploratory, contextual and descriptive research design was used to collect and analyse the data. An exploratory design collects data and gains insight into an unknown area (Creswell 2009; De Vos et al., 2011), while a descriptive design is used to provide an accurate description of a phenomenon (Creswell, 2009). A contextual research design seeks to avoid detaching research participants from the wider setting with which they are associated (Schurink in De Vos et al., 2011). It was regarded as important to view the youths in the specific context of Grabouw.

\section{Population and sampling}

In this study the youths, their parents and also the stakeholders (teachers, community leaders, social workers, school principals) involved and interested in the wellbeing of the youth in Grabouw were the population. Purposive and snowball sampling were seen as appropriate for this particular study. Purposive sampling was used in the selection of the youths in the schools in Grabouw as they contain the characteristics of the population that serve the purpose of the study. All the youths in the three schools between the ages of 14 and 20 were in the focus groups. Originally we planned to draw a sample of youths, but the principals of the schools requested us to interview all children in a particular class and include all in the process. Snowball sampling was used with the teachers, parents and stakeholders as people who could inform the study best. We did not know before the time who they would be and had to rely on the information from the community. Participants involved and interested in the youths' substance abuse were interviewed.

Eight months before the study commenced an observation and a pilot study were also conducted to allow the researchers to become familiarised with the community. The pilot study was vital, because it assisted in identifying barriers and possible stakeholders related to the research process.

\section{Method of data collection}

Data were collected through semi-structured interviews with six (6) parents whose children abused drugs and nine (9) stakeholders from the community, while twenty (20) focus groups were conducted with 6 to 12 youths in a group at the schools in Grabouw. 
By definition a focus group is a goal-directed discussion (Sarantakos, 2005), while De Vos et al. (2011) noted that a semi-structured interview is useful when the researcher wants to gain a thorough representation of participant opinion about, or insights into, or explanations of a certain topic. All the interviews were recorded with the permission of all participants. Creswell's (2009) data-analysis method was utilised. The themes were then linked to Bronfenbrenner's ecological systems theory.

The specific set of people interviewed for this study included:

- One focus group interview with three non-school-going youths involved in substance abuse;

- A youth development officer from the Municipality of Theewaterskloof;

- One school Christian minister and a youth who was previously involved in substance abuse;

- One private family therapist;

- Two social workers;

- One social auxiliary worker;

- Two Social Work interns (4 $4^{\text {th }}$-year students);

- Six parents whose children are using substances;

- Five focus groups with a Grade 12A class of 42 students at High School A;

- Nine focus groups with a Grade 9C class of 53 students at High School B;

- Five focus groups with a Grade 10B class of 42 students at High School C;

- One focus group with 6 male students who are known to be involved in substance abuse/use at High School A.

In recruiting participants the researcher discovered that it was difficult to recruit parents who were willing to participate in the research, but with the help of Riet Drug Abuse Centre in Grabouw, parents were accessed to participate in the study. The school-going youths consisted of users and non-users.

\section{RESEARCH FINDINGS}

The identified themes presented the findings of the study and will be supported by the participants' comments from the transcribed interviews. Neuman (2006:181) states that, "this presentation of direct quotations is found to be common to the qualitative research process and will clearly illustrate the themes described". Furthermore, trustworthiness and credibility will be established through a literature control and triangulation by obtaining data from different sources (Yegidis \& Weinbach, 1996:218). Trustworthiness is further enhanced by linking the themes to Bronfenbrenner's theory. 


\section{Biographical details of research participants}

The following table presents the biographical information of the participants who were involved in the interviews. The sample comprised the 134 youths, who were a mixture of users and non-users, 6 parents of substance abusers, and 9 key informants who work directly with the youths in Grabouw.

TABLE 1

SUMMARY OF THE PARTICIPANTS

\begin{tabular}{|l|c|c|c|c|}
\hline Group & Age range & Males & Females & Total \\
\hline Youth & $14-20$ & 76 & 58 & 134 \\
\hline Key informants & Various adults & 4 & 5 & 9 \\
\hline Parents & Adults & 0 & 6 & 6 \\
\hline & & & Total & $\mathbf{1 4 9}$ \\
\hline
\end{tabular}

The participants were all high school students from three different schools in Grabouw. The key informants in the study are people who work directly with the youth in the community of Grabouw. The third group was the parents who participated in the research study and whose children are involved in substance abuse. It was interesting to note that no father was willing, or could be accessed, to participate in the research.

The following section will present the main themes that developed from the dataanalysis process. The themes includes the comments from all groups interviewed and presented according to Bronfenbrenner's systems.

\section{Themes and subthemes}

\section{THEME 1. THE INDIVIDUAL: REASONS FOR SUBSTANCE ABUSE LINKED} TO THE PERSON

Adolescence is considered by Carr (2006) to take place between the ages of 13 to 20 years, and it is characterised by profound biological, psychological and social developmental change (Sadock \& Sadock, 2007), which makes adolescents vulnerable to using/abusing substances, as will be described. 


\section{DIAGRAM 1 \\ REASONS RELATED TO THE PERSON}

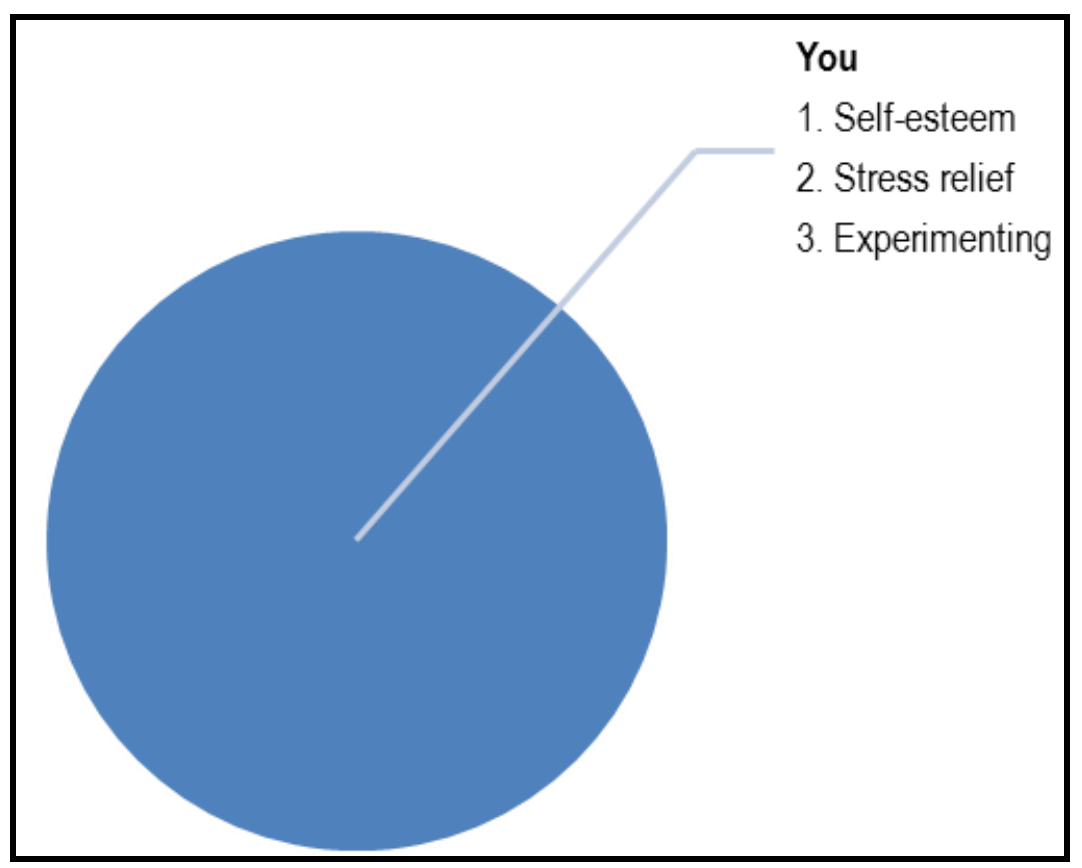

Source: Research data adapted from Bronfenbrenner (1989)

\section{Subtheme 1.1 - Lack of self-esteem}

In this research most of the youths in Grabouw revealed that they have low self-esteem and substance abuse has been their solution to make them feel better, as explained in the following narratives.

"I use Ganga because it will make me laugh and smile at school even when 1 knows in my heart that I am sad."

"I started using drugs to get a false sense of self-esteem; here at school you will find out that there are people with low self-esteem and they cannot seem to improve no matter what kind of help they get; we turn to drugs because we become more active and will be able to do things that we never did before."

The stakeholders shared the following:

"Some start using drugs as a way of improving their low self-esteem, especially when they are shy to perform in public places like in schools, and acting, or singing in concerts."

One of the mothers expressed her view in this regard:

"With my son these days now that he has been living with bipolar, he uses drugs when he feels very low and unimportant."

Self-esteem is described as a person experiencing himself/herself as valuable (Louw \& Louw, 2007). Rosenburg (1986 in Louw \& Louw, 2007) identified different aspects of self-esteem: baseline self-esteem and barometric self-esteem. Barometric self-esteem is "the fluctuating sense of worth and wellbeing people have as they respond to different thoughts, experiences and interactions in the course of the day" (Rosenburg, 1986 in 
Louw \& Louw, 2007). Most adolescents experience barometric self-esteem. Individuals with low baseline self-esteem "usually have poor opinions of themselves, even though they have days when things go right" (Rosenburg, 1986 in Louw \& Louw, 2007:316). Low baseline self-esteem is seen as a risk factor for substance abuse. The study by Botes (2012) also indicates that youths may use drugs to make them feel better about themselves. Chemical substances have been proved to have a function in facilitating relief from internal discomfort by heightening the euphoric experience, as became clear in the next subtheme.

\section{Subtheme 1.2 - Substance abuse as a way of removing stress in the lives of the youth}

In the following narratives various participants showed that they were involved in substance abuse in order to relieve stressful situations in their lives.

"I used drugs to be brave when getting into stressful situations like writing exams or when the principal calls me to his office when I do know that I was wrong."

"In relationships, especially in love relationships, in the event that there are problems in the relationship, people turn to drugs so that they can forget about their problems. But, well, it is a short-term solution; they then keep on taking the drug to the extent that they become addicted."

The social auxiliary worker supported the above statement by saying:

"They (the youths) cannot handle stress and pressure from their homes and they come from homes where mother and father are using drugs. So it's the anger, pressure at home and they see the easiest way out of their problems as using drugs. Dagga is mostly used by our youth to feel better and forget about their stressful situations."

A Grade 10 youth made the following statement illustrating the complexity and multifaceted reason for substance abuse:

"The reason why $l$ started using drugs is because of stressful situations in my life, like not having enough to eat and having too many family responsibilities as a child. For some people they use drugs because they have a long day at school or at work, and when they come from school they will come to stressful families who shout or even abuse them, so it will be difficult to sleep, so one would drug themselves or drink lots of beer and you will sleep like a baby and forget all your problems."

Zastrow (2004) reports that young people usually use illicit drugs as a way of avoiding different stressors in their lives and to create a sense of happiness. Some of the reasons for substance abuse are to manage stressful situations, to normalise painful conditions and for pleasure. NIDA (2006) states that traumatic events can also intensely influence the abuse of alcohol or other drugs, as trauma is a major contributor to the start and continuation of alcohol or other drug abuse. Youths exposed to traumatic events in their lives have a high chance of being involved in substance abuse (NIDA, 2006). 
According to research done by Botes (2012), chemical substances enabled participants to act out sexual fantasies. Botes (2012) also noted that substance abuse could enhance sexual and euphoric experiences. In this study some youths confirmed that they are involved in substance abuse because they want to increase their sexual stimulation and also need to enjoy the after-effects of substance abuse, such as euphoria. This is evident in the following comment:

"The reason why some of us started using drugs was because of the need to have sexual stimulation."

Some responded that they started to use drugs to experience a feeling of euphoria, which is defined as a state of intense happiness and excitement (Oxford Dictionary, 2012). Chemical substances directly affect the human central nervous system and result, amongst various other effects, in a euphoric state (Rosdahl \& Kowalski, 2008; Van Eeden, 2002). Chemical substances have the ability to change the brain's structure and its performance (Van Eeden, 2002) as suggested in the following narratives:

"After my father killed my mother in front of me, I was not happy in my life and in this world. I used Ganga and that thing made me friendly with other people and put a smile on my face and made me enjoy the day."

Another youth says:

"I use Ganga because it makes me laugh and smile at school, even when l know in my heart that l am sad."

One of the parents reported that her daughter said that:

"Drugs made her feel happy and she felt like all her problems were going away."

Nace (in Erlank, 2002) states that substance use is associated with the experiences of relief, relaxation, escape, euphoria and sedation - the changes from the effect are a further motivation for future substance use. The chemical substance user can escape negative emotional effects and create positive experiences.

\section{Subtheme 1.3 - Experimenting with alcohol and drugs}

Experimenting with alcohol and drugs as a reason for substance abuse has been identified as one of the reasons why youths are involved in substance abuse. A parent shared the following about her child:

"He told me that it started as an experiment with the other kids at school and without noticing he was already hooked in drugs. He said he had to do it because all the boys that he was friends with were already using the Tik."

Another parent said:

"She A (daughter) said that it started as her just wanting to know how it will feel like to be high."

The following responses came from the focus group discussions with the youths: 
"You will get curious and want to use it as well, with Tik you only want to use it and then you can get addicted to it."

“... the issue of experimenting because children as young as 8 years old are starting to use."

"Being exposed to drugs in our communities makes it look like it is a good thing to do drugs. This leads to people to want to experiment and they will become addicts."

Arnett (2001:403) indicates that the predominant need to experiment and "see what it is like" and the influence of peers in this regard are also widely recognised as major contributing factors to drug abuse. Louw and Louw (2007) assert that adolescence is a stage where individuals are eager to try out new things and that is when substance abuse is high. Adolescents pick up their substance abuse habits from their society and they view it as something that would make them happy and can take away their life problems (Donald et al., 2007; Parrott et al., 2004); this will be discussed and elaborated on in the next theme.

\section{THEME 2. REASONS RELATED TO THE MICRO SYSTEM OF THE YOUTH: THE FAMILY}

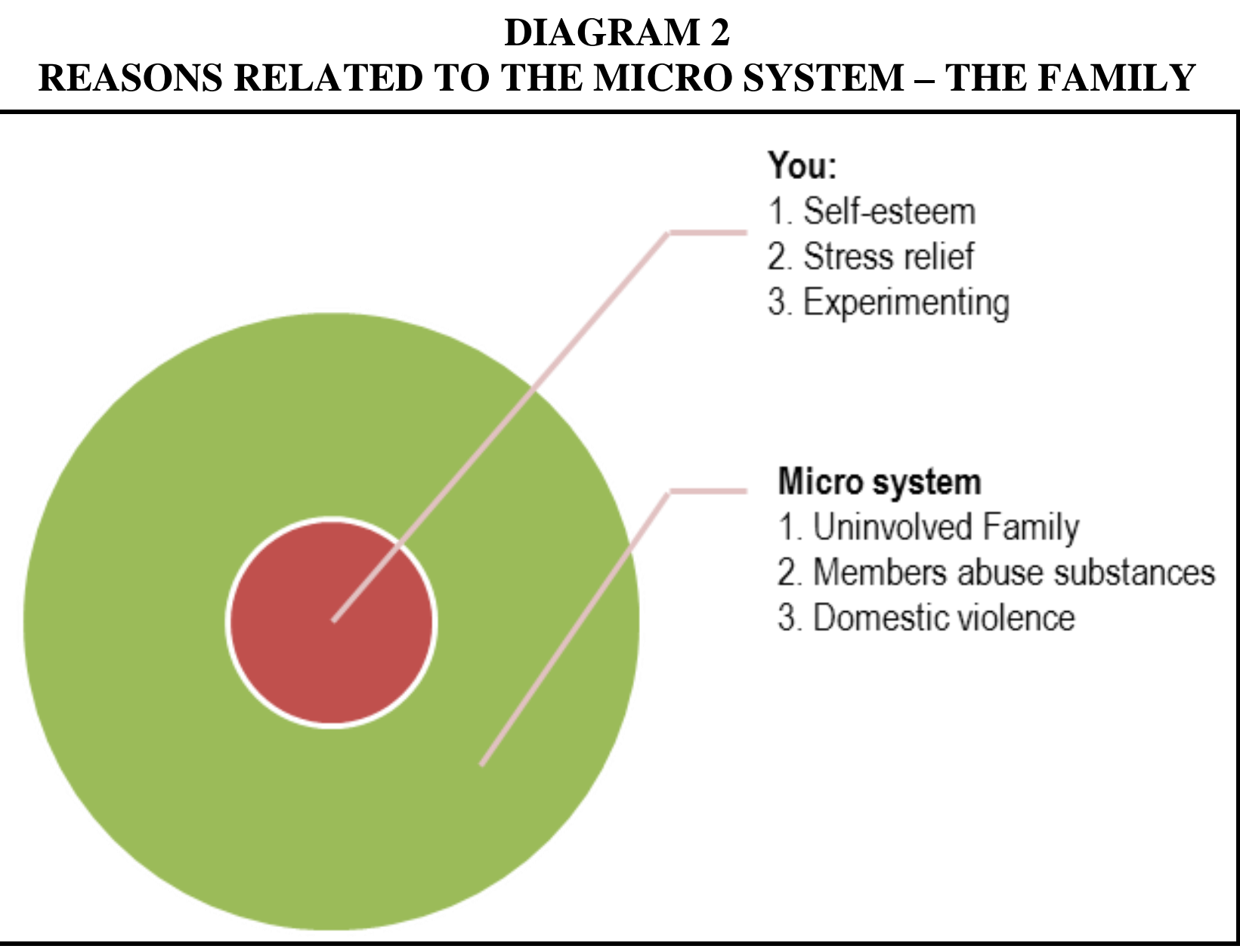

Source: Adapted from Bronfenbrenner (1989) 
According to Hepworth et al. (2008), ecological systems theory maintains that the environment and immediate settings actively shape the outcome of an individual's life. Newman, Harrison, Dashiff and Davies (2008) further add that during this fragile period in an individual's life, at-risk adolescent behaviour is often impacted on by the relationships between the adolescents and their parents. Furthermore, McKinney, Donnelly and Renk (2008) emphasise that the way in which adolescents identify with their parents and bond with them has a significant effect on their later risk of the development of unhealthy behaviours and lifestyles. The family at this stage plays a big part in shaping and protecting the lives of their children (McKinney et al., 2008). The children were reported to come from families who are uninvolved in their lives and family members using/abusing substances. The youths also reported exposure to domestic violence (verbal and physical abuse), not being accepted by family members, and poverty conditions.

\section{Subtheme 2.1 - Uninvolved parents}

The private family therapist who took part in this research emphasised that parents are not involved in their children's lives. The following narratives are the responses from two parents and they show how neglect and absence of a parent in the child's life can cause one to become involved in substance abuse.

"My son told me that he started using drugs because his father neglected him as he grew up and he was left to live with his grandmother and the father was never there."

"She (the daughter) blamed her drinking on me not being there for her all the time and the fact that her grandmother never bothered to ask her how she was feeling or why she was drinking and using drugs."

In a focus group a 15-year-old boy confirmed that lack of parental involvement contributes to substance abuse.

"Also because our parents are never home, they are always busy at the farm, so we do what we want and because we do not have a father in our family, we do what we want because mum does not have total control over us."

Shaffer (2009) and Bukakto and Daehler (2011) agree that uninvolved parents can be described as making few demands, not acting quickly to meet their children's needs, and not talking together frequently. Even though these parents supply the adolescent's simple necessities, they are in general disconnected from their adolescent's life and in serious situations they may even abandon their responsibility to meet the needs of their children (Bukakto \& Daehler, 2011; Shaffer, 2009). This lack of nurturing impacts negatively on children, who then tend to have low self-esteem and lack self-control, making them more prone to be affected by peer pressure and experimentation with drugs in a bid to boost their confidence (Shaffer, 2009).

Uninvolved parents are described as those who are less attentive to their children's needs, because they have either refused to undertake their parental responsibility or they are dealing with their own personal stressful issues and they do not find time and energy 
to commit to their parental duties (Kail \& Cavanaugh, 2013; Maccoby \& Martin, 1983 in Shaffer, 2009).

\section{Subtheme 2.2 - Family members using/abusing substances}

With regards to family influence, various participants confirmed that the reason why some of the youths are involved in substance abuse is that they were brought up in homes where the parents/family members and other siblings are using drugs. A social worker mentioned that

"they come from homes where the mother is using tik and the father is using ... drugs and the child sees nothing wrong with using as well."

One of the youths confirms this:

"Because of the parents who use drugs as well and also problems that we see at home, it makes us want to use drugs and makes us forget about everything."

Two youths also added that they started using drugs because other family members are also using. The comment from the youth confirms the link between the substance abuse of the parents and their lack of involvement with their children:

"Our parents drink too much to the extent that they do not take care of us as children, so the best option is to join them and do what they are doing."

One of the children, who is not a substance user but has friends who use drugs, said the following about why his friends are involved in substance abuse:

"(they) use drugs because their parents do the same, so they don't see it as wrong; it's their way of life."

In relation to this, Arnett (2001) and Butcher, Mineka and Hooley (2007) write that adolescents are more inclined to use illicit substances when one or more of their family members have a tolerant or lenient attitude towards substance use or use it themselves. Gwinnell and Adamec (2006) explain that some adolescents may be modelling their own parents who use substances, as some of the participants indicated.

"Yes, my brother uses Ganga and my father uses button. I watch them using and that is how l learnt to do it as well."

"They are brought up in houses where parents are using, brothers and sisters are using, so it's easier to get into it because everyone is using."

Parents who are illicit substance users have a higher chance of raising children who will later follow their pattern of drug and alcohol use. The longer the family denies that they are faced with alcohol and drug problems, the more vulnerable the family members become. Absence of parental management of children because of the parent's heavy drinking and drug dependence makes children in that family four to eight times more likely to develop problems with alcohol and drugs (Kirisci et al., 2009).

\section{Subtheme 2.3 - Domestic violence}

Physical and emotional abuse within the family system was an aspect which was emphasised in the narratives given by the youths and the key informants. De Genova and 
Rice (2002) refer to family violence as any harsh, boisterous, physical force or aggression, or verbal abuse by one family member towards another. Different participants stated that the reason they started using substances was because they were exposed to incidences of domestic violence. An auxiliary social worker said:

"it can be violence, it can be abuse outside and inside the home and that person doesn't really have a place to stay."

The youths commented as follows:

"before my eyes like truly my father killed my mother. After that l was not happy in my life and in this world so I did use ganja like I told you. I don't like the word dagga because it is ugly. That thing makes you friendly with other people; it just puts a smile on your face and makes you enjoy the day.'

"I use drugs because my parents use drugs as well and also problems that we see at home such as when my father is abusing my mother beating her and shouting at her all the time; it makes us want to use drugs and make us forget about everything."

One of the parents also said:

"l have been living in an abusive relationship with my husband, he is an alcoholic and when he comes home most of the times he shouts at me and the children for no reason, and when I try to make him stop he physically attacks me in front of the children. This has been affecting my son and he said to me one day, 'Mommy I would rather be high on drugs every day of my life so that I will not have to see the pain you are getting from what dad is doing to you'. So I think for him taking drugs is a way of him dealing with our bad circumstances."

Dube et al. (2001) explain that children mistreated at the hands of their families or society have a high probability of being involved in substance abuse in their lives. All forms of mistreatment of children are therefore regarded as possible influences leading to illicit drug use (Moran, Vuchinich \& Hall, 2004). In a study done at a public school in the USA, it was found that students who have been abused sexually and physically have a higher rate of using drugs than the ones who were not abused. Substance abuse was seen as a way of dealing with these traumatic incidents (Perkins \& Jones, 2004).

\section{THEME 3. MESO SYSTEM: PEER GROUP INFLUENCES}

Peers were the only factor in the meso system mentioned by the youths.

Gwinnell and Adamec (2006:195) define peer pressure as "influence from individuals that a person regards as equal to perform acts that the individual might not choose to do on her/his own". Peer pressure, with the need to feel part of a certain group of friends, was pointed out by almost all the participants as one of the reasons why they started using drugs or alcohol. Some of the youths will see themselves as part of a gang, and as part of the gang-related rules their peers/gang members will coerce them into drugtaking as an initiation into the gang. The need to belong to a gang shows their need for 
affection and acceptance. The peer group often has to replace the uninvolved family and it could be argued that the peers are actually part of the micro system.

\section{DIAGRAM 3 \\ REASONS RELATED TO THE MESO SYSTEM: PEER INFLUENCES}

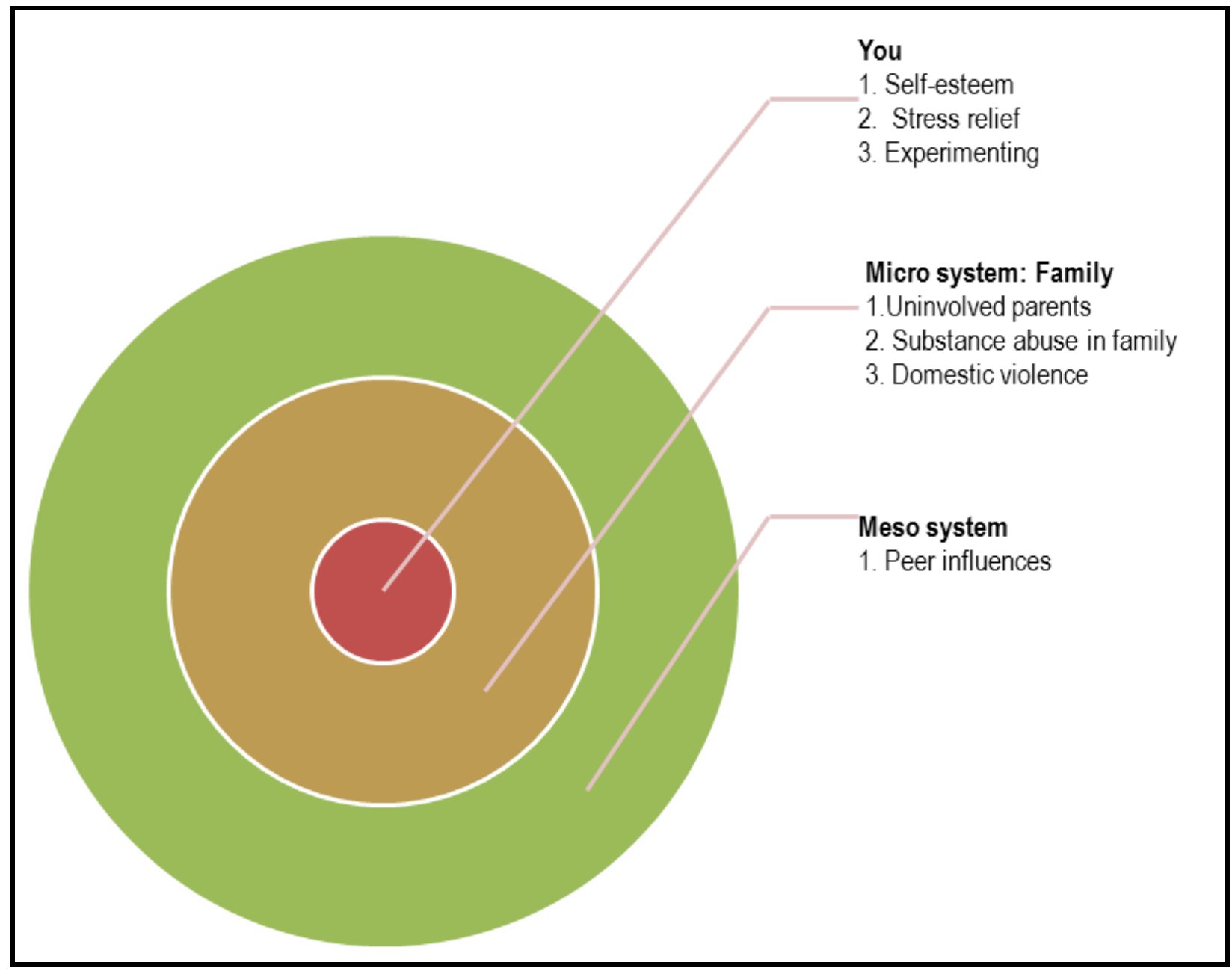

Source: Research data and adapted from Bronfenbrenner (1989)

Comments from the youths regarding their peers included the following:

"We always want to impress our friends, so we do whatever what they do, that is how I started using drugs because all my friends were using it and it looked very cool."

"I use button (a mixture of over the counter pills and any other drug such as cocaine or dagga) and tik and I get it from my brothers and their friends."

"I started using drugs because I saw my friends using and that's when I started practising as well."

"Peer pressure, friends, as she said everybody in your environment is using, so maybe it is even harder not to use, when everyone around you is using."

The pharmacist from Grabouw Clinic said that: 
"Wanting to have a sense of belonging, so in order to join the so-called cool kids in the community one has to experiment with certain drugs and later become an addict."

A social worker supported the above statements about peer pressure:

"With the youth most of the times when it comes to gang-related rules when one joins the group, you will have to do what the rest of the members do, like taking a certain drug.

Peer pressure was further highlighted by parents:

"...problem is that in the area we live people of his own age are using drugs, so maybe peer pressure is the major cause of his drug taking behaviour."

Hoberg (2001:253) points out that adolescents "constantly seek reassurance and acceptance by peers". Genius (2003) states that the fear of being rejected often influences decisions and choices regarding engaging in certain activities. He further states that adolescents often believe that they will earn the respect of their friends and be viewed more favourably if they follow what is being perceived as a social norm, as in the case of substance use. This need for companionship, belonging, acceptance and approval becomes of particularly great importance if you did not receive this at home.

\section{THEME 4. MACRO SYSTEM}

The macro system refers to the socio-economic, environmental and political context of the youths. 


\section{DIAGRAM 4 \\ REASONS RELATED TO THE MACRO SYSTEM.}

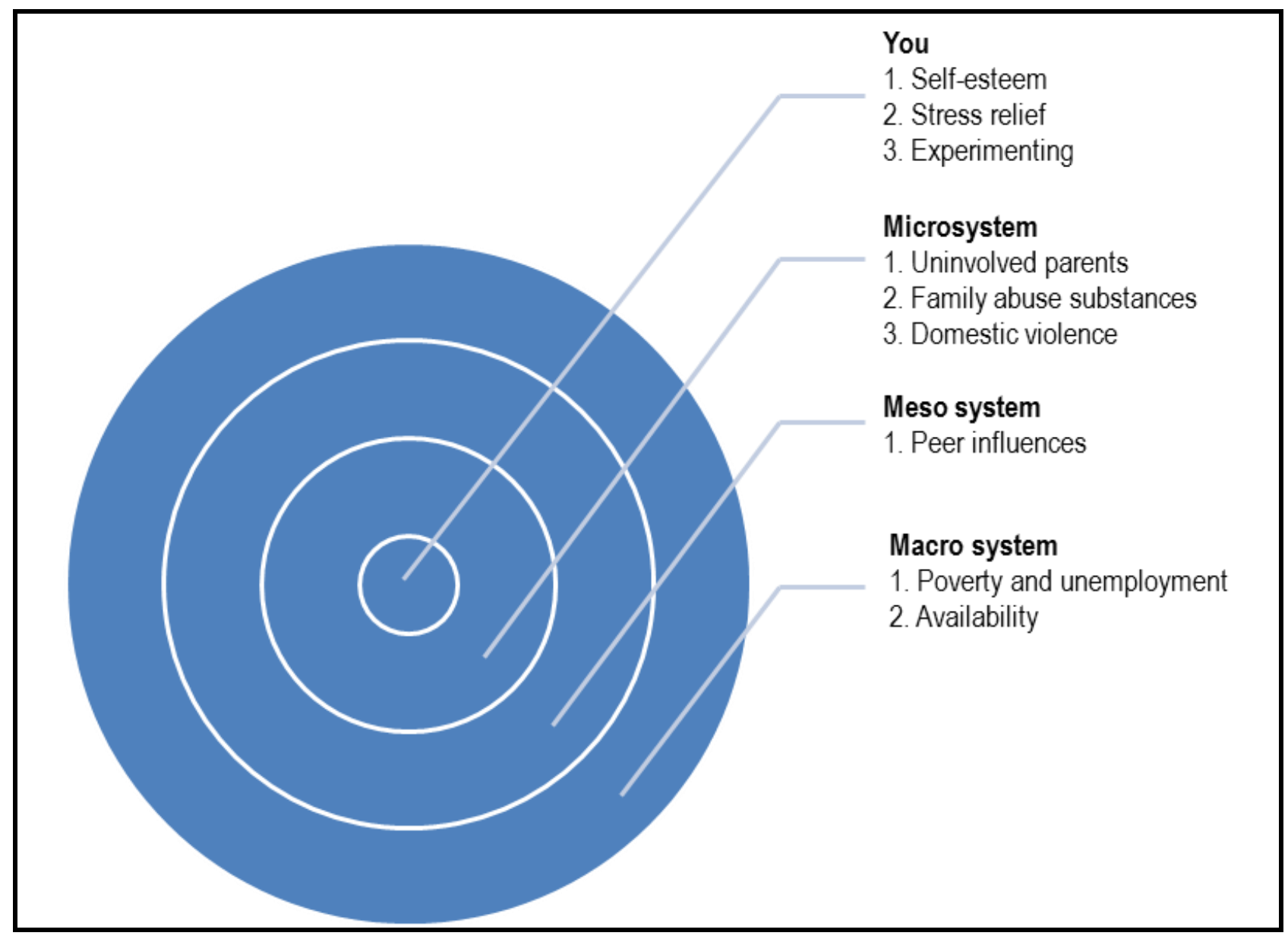

Source: Research data and adapted from Bronfenbrenner (1989)

\section{Subtheme 4.1 - Poverty and unemployment}

Because of unemployment and financial struggles many families in Grabouw are living in conditions of extreme poverty and this has impacted on the lives of the youths. An auxiliary social worker stated:

"Poverty also plays a role here, parents cannot provide ... because they are vulnerable and the people who see that the child is in need, they take advantage of that, and they tell them that this is the easy way for you to make pocket money, buy yourself a cool drink or a Blackberry phone. So at the end of the day they end up making pocket money or end up getting addicted with the drugs because they usually end up taking drugs as well."

One of the youth commented:

"Stressful situations such as not having enough to eat, too many family responsibilities, is what makes us youth use drugs. You know, just to be able to forget poverty for a while."

Roberts (2003) supports the above narratives stating that living in extremely poor conditions has a major impact on families, as they will be faced with too much pressure 
and the parents may not be able to nurture their children in a setting which is conducive to developing positive and supportive attitudes. For that reason children from these kinds of families have a higher risk of using illicit drugs in their lives, particularly if this is coupled with absent parents or parents who abuse substances themselves.

One of the key informants who worked directly with the youths in Grabouw shared that unemployment and idleness among the youths who completed school and the school drop outs are the major causes of substance abuse in the district:

"Unemployment is a major obstacle in Grabouw. There is nothing to do for the youth in this community, some youths feel hopeless and it seems as if there is no one to cultivate the hope within these youths, teaching them new skills ... Not having anything to do, that's when they start experimenting with drugs just to keep themselves occupied, but in the long run they will get addicted."

The World Drug Report (2012) confirms that unemployment is one of the key socioeconomic drivers of substance use and drug trafficking. Being unemployed creates boredom. A youth development officer and some of the youths confirmed that boredom pave the way for the youths to become involved in substance abuse as they find themselves with nothing to do after school and work hours:

"...nothing to do, so no job, no school, in fact for some people there is no school, no job in particular, that is when they start taking the substances."

Of greater concern is that the poverty and boredom pave the way for unlawful activities such as prostitution, robbery, rape and even murder.

"Some girls use drugs so that when they go to the bar to do prostitution and stripping, they will not be shy and drugs do magic in hiding the fear within people's hearts."

"When you get yourself involved with the wrong crowd, they can make you do something stupid, like maybe make you kill someone or make you steal, so for you to get courage and motivation to do this you have to take drugs."

The above disturbing narratives are further supported by the collective research results published by the World Drug Report (2012), which states that there are various ways in which substance abuse is directly associated with the fact that drug users turn to crime for them to sustain their drug-taking habits. In general, there are higher levels of drug use among criminals compared to the rest of the population. Furthermore, most of the criminals will be under the influence of illicit drugs whilst committing the crimes (World Drug Report, 2012). Crime is also related to drug trading and the money that they get from trading the drugs is used to fund more criminal activities such as those of illegally armed gangs. Usually when gangs are formed, it means there is more violence in the communities (World Drug Report, 2012).

\section{Subtheme 4.2 - Availability and affordability of substances}

Despite the regulations which prohibit alcohol being sold to under-age children, drugs and alcohol seem to be easily available and affordable for everyone. The following 
narratives show how available and affordable substances that may be abused are in the community of Grabouw.

"Some of the youths in Grabouw abuse drugs and alcohol simply because it's easily available and affordable."

"Drugs are everywhere, in school, in almost every corner of their neighbourhoods, one just has to know who to talk to."

"They can be accessed from a common kitchen, so over the years tik is sold in the communities and the drug smuggler will buy the pure tik and they will go home, add some detergents such as window cleaner, Handy Andy (ammoniabased cleaning detergent) and battery acid; they add it and it is sold on the streets and it's readily available to everyone."

"Tjo, it is so easily available these days and I think it's not a problem to get them and as far as I know you can even get them on the school premises, in the neighbourhoods they stay there are drug dealers that they can purchase it from."

NSDUH (2010) confirms that among the main factors to explain substance use/abuse is how accessible it is and how people view the effects from the use of drugs on the user and the environment.

\section{CONCLUSIONS AND RECOMMENDATIONS}

The words of one of the participants provide a good summary of this article:

"One of the difficulties that our youths are faced with ... is lack of identity; that all stems from how one was raised, religion, morals and values are the issues that make the child easy to align or embrace wrong things or anything that makes you feel special."

This comment summarises the Bronfenbrenner's ecological systems theory and the interaction between the person and his context. In particular the link between the family and substance abuse can be highlighted as the immediate and most important context in which the child is raised and his/her identity formed. If the family do not provide a favourable context, then peers and other aspects such as easily accessible substances will have an influence, as this study shows. It is a matter of concern that the context of poverty, domestic violence, easy access to drugs, exploitation and little care for the youths exists in some parts of the community.

The message to social service professionals and policy makers is clear. We have to assist families in raising healthy individuals, promote healthy marriages and families, encourage involved parents, parents who care about themselves and those around them and in particular their children. We have to focus on the wellbeing of the youths, but in particular on the wellbeing of the parents to have the physical and emotional energy to be involved with their children. We need to facilitate healthy socio-economic environments in which families are able to live dignified lives. 
Feedback on the research results was shared with the community of Grabouw. We do not have reason to think that the results of similar research in other towns and cities will be very different. The community of Grabouw can be commended for taking this bold step to reflect critically on the nature of their community. This is the first step to building hope. A follow-up appreciative study is planned to assist in the way forward.

\section{REFERENCES}

ADAMS, R., DOMINELLI, L. \& PAYNE, M. 2009. Social work themes, issues and critical debates $\left(3^{\text {rd }}\right.$ ed). Palgrave: MacMillan.

ARNETT, J.J. 2001. Adolescence and emerging adulthood: a cultural approach. Upper Saddle River, New Jersey: Prentice-Hall.

BABBIE, E. \& MOUTON, J. 2001. The practice of social research. England: Oxford University Press.

BANISTER, P., BURMAN, E., PARKER, I., TAYLOR, M. \& TINDALL, C. 1998. The sage handbook of Qualitative Research in Psychology. London: Sage Publications.

BAUMRIND, D. 1991. The influence of parenting style on adolescent competence and substance use. Journal of Early Adolescence, 11(1):56-95.

BERK, L.E. 2007. Development through the lifespan $\left(4^{\text {th }}\right.$ ed $)$. Boston: Pearson Education Inc.

BOTES, J.H. 2012. Exploring the functions of chemical substances in individuals' sexual behaviour. South Africa: University of South Africa.

BRONFENBRENNER, U. 1989. The ecology of human development: experiments by nature and design. USA: Library of Congress.

BUKAKTO, D. \& DAEHLER, M. 2011. Child development: a thematic approach. Belmont: Wadsworth.

BUtCHER, J.N., MINEKA, S. \& HOOLEY, J.M. 2007. Abnormal Psychology. Boston: Allyn \& Bacon.

CARR. A. 2006. The Handbook of child and adolescent psychology: a contextual approach. London: Routledge.

CHOPRA, M. \& SAUNDERS, D. 2004. From Apartheid to Globalisation: health and social change in South Africa. Hygiea Internationalis, 4(1):153-174. 
CRESWELL, J.W. 2009. Research design: qualitative, quantitative and mixed approaches. Thousand Oaks: Sage Publishers.

DE GENOVA, M.K. \& RICE, F.P. 2002. Intimate relationships, marriages, and families. Boston: McGraw Hill.

DE VOS, A.S., STRYDOM, H., FOUCHÉ, C.B. \& DELPORT, C.S.L. 2011. Research at grass roots - for the social science and human service professions $\left(3^{\text {rd }} \mathrm{ed}\right)$. Pretoria: Van Schaik Publishers.

DONALD, D., LAZARUS, S. \& PELIWE, L. 2007. Educational Psychology in social context $\left(3^{\text {rd }}\right.$ ed). Cape Town: Oxford University Press.

DUBE, S.R., ANDA, R.F., FELITTI, V., CHAPMAN, D., WILLIAMSON, D.F. \& GILES, W.H. 2001. Childhood abuse, household dysfunction and the risk of attempted suicide throughout the life span: findings from the Adverse Childhood Experiences Study. Journal of the American Medical Association, 286:3089-3096.

ELLIS, G.F.R., STEIN, D.J., THOMAS, K.G.F. \& MEINTJES, E.M. 2012. Substance use and abuse in South Africa. South Africa: CT Press.

ERLANK, E.C. 2002. Die substansafhanklike geneesheer, 'n maatskaplikewerk perspektief. Pretoria: University of Pretoria. (Unpublished DPhil thesis)

FLICK, U. 1992. Triangulation revisited: strategy of validation or alternative? Journal for the theory of social behaviour, 22:175-198.

GENIUS, S. 2003. Talk to your teen about sex. [Online] Available: http://www. womantodaymagazine.com/fitnesshealth/teensex.htm/?a=1187. [Accessed: 02/09/2013].

GRAZIANO, A.M. \& RAULIN, M.L. 2010. Research methods. A process of inquiry. USA: Allyn \& Bacon Publications.

GREENE, R.R. 2011. Human behavior theory and social work practice. USA: Library of Congress.

GWINNELL, E. \& ADAMEC, C. 2006. The encyclopaedia of addictions and addictive behaviours. USA: Facts on file Inc.

HENNING, E., VAN RENSBURG, W. \& SMITH B. 2004. Finding your way in qualitative research. Pretoria: Van Schaik Publishers.

HEPWORTH, D.H., ROONEY, R.H., ROONEY, G.D. \& LARSEN, J.A. 2008. Direct social work practice theory and skills. USA: Brooks/Cole. 
HOBERG, S.M. 2001. Adolescent substance abuse: perspectives on club drugs. Journal of the Faculty of Education, 30:249-271.

HOWE, D. 2009. A brief introduction to social work. UK: Palgrave MacMillan.

JACOBS, S.N. 2012. Financial and fiscal commission: public hearings, sustainable financing of local government. Grabouw: Western Cape.

JAFFE, M.L. 1998. Adolescence. New York: John Wiley \& Sons.

KAIL, R.V. \& CAVANAUGH, J.C. 2013. Human development: a life-span view $\left(6^{\text {th }}\right.$ ed). USA: Library of Congress.

KIRISCI, L., TARTER, R., MEZZICH, A., RIDENOUR, T., REYNOLDS, M. \& VANYUKOV, M. 2009. Prediction of cannabis use disorder between boyhood and young adulthood: clarifying the phenotype and environ type. American Journal on Addictions. The official Journal of the American Academy of Addiction Psychiatry, 18(1):36-47.

KIRST-ASHMAN, K.K. \& HULL, G.H. 2009. Generalistic practice with organisations and communities. USA: Brooke/Cole.

KRUEGER, R. A.A. 2009. Focus groups: a practical guide for applied research $\left(4^{\text {th }}\right.$ ed). USA: Sage Publications.

LIDDLE, H. \& ROWE, C.L. 2006. Adolescent substance abuse: research and clinical advances. New York: Cambridge University Press.

LOUW, D. \& LOUW, A. 2007. Child and adolescent development. Bloemfontein: Psychology publications.

MADU, S.N. \& MATLA, M.P.Q. 2003. Illicit drug use, cigarette smoking and alcohol. Drinking behavior among a sample of high school adolescents in the Pietersburg Area of the Northern Province, South Africa. Journal of Adolescence, 26(1):121-136.

McKINNEY, C., DONNELLY, R. \& RENK, K. 2008. Perceived parenting, positive and negative perceptions of parents, and late adolescent emotional adjustment. Child and Adolescent Mental Health, 13(2):66-73.

MORAN, P., VUCHINICH, S. \& HALL, N. 2004. Associations between types of maltreatment and substance use during adolescence. Child Abuse \& Neglect, 28:565574. 
NATIONAL INSTITUTE ON DRUG ABUSE. 2003. Preventing drug abuse amongst children and adolescents (In brief). [Online] Available: http://www.drugabuse.gov/ publications/preventing-drug-abuse-among-children-adolescents [Accessed: 25/03/2012].

NATIONAL HEALTH AND MEDICAL RESEARCH COUNCIL (NHMRC). 2009. Australian guidelines to reduce health risks from alcohol. Canberra: Commonwealth of Australia.

NATIONAL SURVEY ON DRUG USE AND HEALTH ( NSDUH). 2010. [Online] Available: http://www.samhsa.gov/newsroom/advisories/1109075503.aspx [Accessed: 18/04/2012].

NEUMAN, W.L. 2006. Social research methods: qualitative and quantitative approaches $\left(4^{\text {th }}\right.$ ed). New York: Allyn \& Bacon.

NEWMAN, K., HARRISON, L., DASHIFF, C. \& DAVIES, S. 2008. Relationships between parenting styles and risk behaviours in adolescent health. An Integrative Literature Review. Rev Latino-am Enfermagem janeiro-fevereiro, 16(1):142-150.

NIDA. 2002, updated: 2006. Community Drug Alert Bulletin - stress \& substance abuse. [Online] Available: http://archives.drugabuse.gov/StressAlert/stressalert.html Oxford Dictionary, 2011. UK: Oxford University Press.

PARROTT, A., MORINAN, A., MOSS, A. \& SCHOLEY, A. 2004. Understanding drugs and behaviour. United Kingdom: John Wiley \& Sons.

PARRY, C.D.H. 1998. Substance abuse in South Africa. Country report focusing on young persons. [Online] Available: http://www.sahealthinfo.net/admodule/Suchtmed.pdf. [Accessed: 17/04/2012].

PERKINS, D. \& JONES K. 2004. Risk behaviours and resiliency within physically abused adolescents. Child Abuse \& Neglect, 28:547-563.

RAMLAGAN, S., PELTZER, K. \& MATSEKE, G. 2010. Epidemiology of drug abuse treatment in South Africa 16(2):40-48.

RICE, F.P. \& DOLGIN, K.G. 2008. The adolescent: development, relationships and culture $\left(12^{\text {th }}\right.$ ed). Boston: Pearson Education, Inc.

ROBERTS, M., KLEIN, A. \& TRACE, M. 2003. Global policies on illegal drugs. Beckley Report One. London: Drug Scope.

ROSDAHL, C.B. \& KOWALSKI, M.T. 2008. Text book of basic nursing $\left(9^{\text {th }}\right.$ ed). Wolters Kluwer: Lippincott \& Wilkins. 
SADOCK, B. \& SADOCK, V.A. 2007. Synopsis of Psychiatry Behavioural Sciences / Clinical Psychiatry. New York: Lippincott Publishers

SARANTAKOS, S. 2005. Social research $\left(3^{\text {rd }}\right.$ ed $)$. Palgrave: MacMillan.

SEGGIE, J. 2012. Alcohol and South Africa's youth. South African Medical Journal 102(7). [Online] Available: http://www.samj.org.za/index.php/samj/article/view/6003/ 4278. [Accessed: 13/11/2013].

SHAFFER, D.R. 2009. Social and personality development. USA: Library of Congress.

SOUTH AFRICAN COMMUNITY EPIDIOMOLOGICAL NETWORK ON DRUG USE (SACENDU). 2011. [Online] Available: http://www.sahealthinfo.co.za/admodule/ sacendu.htm. [Accessed: 20/10/2013].

STATISTICS SOUTH AFRICA (StatsSA). 2011. Census. [Online] Available: http:// www.statssa.gov.za/Publications/P03014/P030142011.pdf. [Accessed: 20/09/2013].

THEEWATERSKLOOF MUNICIPALITY. $3^{\text {rd }}$ Generation IDP 2012-2017. [Online] Available: www.westerncape.gov.za/assets/departments/.../twk-idp-2013-2014.pdf [Accessed: 01/10/2013].

THORN, S. 2000. Data analysis in qualitative research evidence based nursing. London: Sage Publications.

VAN EEDEN, R. 2002. Drug, facts, arguments and practical advice. Pretoria. Doctors for Life.

VISSER, M. 2003. Risk behaviour of primary school learners in a disadvantaged community: a situation analysis. South African Journal of Education, 23(1):58-64.

WORLD DRUG REPORT. 2008. United national office of drugs and crime. [Online] Available: https://www.google.co.za/?gws_rd=ssl\#q=unodc+2008+world+drug+report.

WORLD DRUG REPORT. 2012. [Online] Available: http://www.unodc.org/unodc/en/ data-and-analysis/WDR-2012.html. [Accessed: 28/03/2013].

YEGIDIS, B.L. \& WEINBACH, R.W. 1996. Research methods for social workers. USA: Allyn and Bacon.

ZASTROW, C. 2004. Introduction to social work and social welfare: empowering people. Belmont CA.: Brooks/Cole. 
Ms Naome Mudavanhu, post graduate student; Prof Rinie Schenck, Department of Social Work University of the Western Cape, Bellville, South Africa. 